\title{
White Feminist Gaslighting
}

\author{
Nora Berenstain
}

Forthcoming in Hypatia

(please cite final version)

\begin{abstract}
Structural gaslighting arises when conceptual work functions to obscure the nonaccidental connections between structures of oppression and the patterns of harm they produce and license. This paper examines the role that structural gaslighting plays in white feminist methodology and epistemology using Fricker's (2007) discussion of hermeneutical injustice as an illustration. Fricker's work produces structural gaslighting through several methods: i) the outright denial of the role that structural oppression plays in producing interpretive harm, ii) the use of single-axis conceptual resources to understand intersectional oppression, and iii) the failure to recognize the legacy of women of color's epistemic resistance work surrounding the issue of sexual harassment in the workplace. I argue that Fricker's whitewashed discussion of epistemic resistance to sexual harassment in the United States is a form of structural gaslighting that fails to treat women of color as knowers and exemplifies the strategic forgetting that is a central methodological tactic of white feminism.
\end{abstract}

"First and foremost, I aim to issue a caution . . When addressing and identifying forms of epistemic oppression one needs to endeavor not to perpetuate epistemic oppression."

- Kristie Dotson $(2012,24)$

"By talking about words, as we have seen them marshalled in the discussion, we hope to provide more clues to the duplicitous involvement of much of feminist thinking in the mythological fortunes (words and images) of patriarchal power."

- Hortense Spillers $(1984,159)$

\section{Structural Gaslighting}

Structural gaslighting is a hallmark of white feminist methodology. This is not the type of gaslighting popularized in the 1944 Ingrid Bergman movie Gaslight, when one person knowingly, intentionally, and consistently undermines the perceptions of another with the goals 
of making them appear 'crazy' to others, feel like they are losing their mind, and genuinely doubt their own grasp on reality. That more widely known type of gaslighting is certainly pervasive, deeply harmful, and a hallmark of emotionally abusive relationships - romantic, familial, and otherwise. Structural gaslighting, on the other hand, is less widely recognized than the traditional conception of gaslighting despite being significantly more pervasive and causing harm beyond the scale of individual psychology.

Structural gaslighting describes any conceptual work that functions to obscure the nonaccidental connections between structures of oppression and the patterns of harm that they produce and license. Individuals engage in structural gaslighting when they invoke epistemologies and ideologies of domination that actively disappear and obscure the actual causes, mechanisms, and effects of oppression. Structural oppressions are maintained in part through systems of justification that locate the causes of pervasive inequalities in flaws of the oppressed groups themselves while obscuring the social systems and mechanisms of power that uphold it. ${ }^{1}$ Davis and Ernst (2017) identify the practice of normalizing white supremacy by pathologizing resistance to it as a form of racial gaslighting. Structural gaslighting, of which racial gaslighting is a type, is one of the ways oppressors maintain hegemonic ideologies and sabotage conceptual resources that might accurately theorize the nature of the oppression and promote resistance. Structural gaslighting is thus deeply interwoven with intersecting structures of oppression and the willful ignorance that is required to maintain them.

In this paper, I analyze some features of the pervasive practice of structural gaslighting as it is employed within white feminist epistemology. I look to Fricker's (2007) discussion of hermeneutical injustice as a paradigm example of white feminist structural gaslighting. I argue that Fricker's use of a single-axis lens of gender-based oppression to analyze both experiences of sexual harassment and the conceptual landscapes that surround them obscures the non-accidental relationships between the production of sexual harassment and the structures of oppression and colonization that support it. I illustrate this by discussing some of the ways that historical and contemporary structures of racism enable both the sexual harassment of women of color in U.S. contexts and facilitate the covering myths that help to erase and obscure its systematicity. In particular, I look at the ongoing structural vulnerabilities that began under slavery which continue to make Black women susceptible to sexual harassment today and I analyze some of the hermeneutical tools that work to obscure this reality. Given that women of color have been theorizing sexual harassment for as long as they have been experiencing it, by ignoring the conceptual knowledge produced by women of color on the phenomenon of sexual harassment and the norms, practices, and systems that license it, Fricker fails to treat women of color as

\footnotetext{
${ }^{1}$ See Collins (2000) for extensive discussion of how ideology functions to make oppression seem "natural, normal, and inevitable."
} 
knowledge creators. Since Fricker's omissions and evasions both depend on the ideologies of and function to uphold colonialism and white supremacy, they are emblematic of the structural gaslighting that white feminism traffics in.

One way that structural gaslighting upholds oppression is by denying that marginalized people's experiences are informed, influenced, or partially constituted by structures of oppression and settler colonialism. This includes experiences of cultural genocide, sexual violence, racism, sexism, ableism, transmisogyny and transphobia, misogynoir, homophobia, heterosexism, classism. Conceptually severing individual instances and broader patterns of discrimination, violence, and oppression from the larger structures that produce them is a linchpin of structural gaslighting. Individuals, institutions, and social groups engage in structural gaslighting, regardless of whether they intend to do so, when they invoke oppressive ideologies, disappear or obscure the actual causes and mechanisms of oppression, and conceptually sever acts of oppression from the structures that produce them.

Structural gaslighting is not identified in terms of any specific intention or goal of the perpetrator but by the function of its operation. Indeed, structural gaslighting is often perpetrated by people who are 'well-intentioned' or who identify as 'allies' (McKinnon 2017). ${ }^{2}$ Pohlhaus (2017) similarly recognizes the relative insignificance of intention when she defines her version of epistemic gaslighting in terms of its effective function rather than in terms of any individual agent's intentional attitudes. ${ }^{3}$ Just as specific intentions are not required for an individual to engage in active or willful ignorance, neither are they required for an agent to be a perpetrator of gaslighting. Indeed, a conception of structural gaslighting appears to be operating in the

\footnotetext{
${ }^{2}$ McKinnon (2017) shows that purported allies are uniquely positioned to produce harm through structural gaslighting due to their presumed good intentions and knowledge. McKinnon clearly recognize that structures of oppression create non-accidental capacities for dominant groups to engage in gaslighting and set up conditions that make marginalized groups vulnerable to it. She analyzes some of the specific structural conditions that create the capacity for cisgender 'allies' to epistemically gaslight trans women in the struggle against transmisogynistic oppression. McKinnon offers a case where a trans woman, Victoria, raises a worry to a colleague, Susan, about having been repeatedly misgendered by another colleague, James. Susan dismisses Victoria's concern as overly emotional and says that she has never heard James use the wrong pronoun and claims that he is really Victoria's ally. Susan's gaslighting of Victoria not only isolates her and contributes to a hostile work environment, it is a special form of betrayal because it comes from someone who purports to be Victoria's ally. When a person who purports to stand in solidarity with members of an oppressed group denies and dismisses a group member's accurate perception of their experiences with oppression, the harms can be significant.

${ }^{3}$ Pohlhaus's epistemic gaslighting does not require that there be a specific agent who is the perpetrator. Pohlhaus describes epistemic gaslighting as occurring "when a person, practice, image, or institution exerts unwarranted pressure on an epistemic agent to doubt their own perception." For Pohlhaus, the hallmark of this form of gaslighting is that the practice directs a person to perceive the world in a way that is both unwarranted and that puts them at odds with their own experience. This is another accurate way to characterize the gaslighting that takes place both in McKinnon's example and in the case of Fricker's work that is discussed here.
} 
background of various accounts of willful or active ignorance. ${ }^{4}$ Mills's (2007) account of white ignorance, adapted from Frye's (1983) work, describes an epistemological system that requires structural gaslighting to carry out functions. White supremacy brings with it a set of standards of cognition that encompass an agreement by dominant agents to misinterpret the world. ${ }^{5}$ Systemic misunderstanding about the intertwined structures of white supremacy and settler colonialism takes a great deal of work to uphold and maintain. This is the work of structural gaslighting. Structural gaslighting can thus be characterized by the fact that it both draws its power from and simultaneously reinforces structural oppression in an unending positive feedback loop.

Ruíz (2012, 2014, forthcoming) further conceives of gaslighting as something that occurs not only at structural scales but at pre-structural one as well. In (2012), Ruíz shows how European colonization disrupted pre-colonial ways of knowing in what is now identified as Latin America and tracks how colonial lineages create public policies, institutions, and political structures that reify and solidify settler epistemologies as the only legitimate form of knowledge. Colonialism's foreclosure of Amerindian linguistic communities' ability to collectively engage in interpretive processes of culture - and be heard and understood as coherent — is thus not only essential to understanding the multiplicity of social oppressions and their intersections in contemporary Latin American contexts; it is also a form of pre-structural gaslighting. Colonial violence is built into the very foundation of the contemporary hermeneutic frameworks that structure human experience in settler societies. One outcome of this is that the concept of violence in settler epistemologies non-accidentally excludes violence done to land, waterways, artifacts, and other loci of meaningful social relations and webs of knowledge within Indigenous epistemologies — what Ruíz (2019a, 2019b) calls hermeneutic violence. ${ }^{6}$ Notably, the gaslighting Ruíz describes is not just a result of the structural automation of colonial epistemologies and institutions. Rather, as a central feature of the genocides that made and continue to make settler institutions possible, this gaslighting was a precondition on the existence of self-propagating

\footnotetext{
${ }^{4}$ Pohlhaus's (2012) account of willful hermeneutical ignorance, for instance, characterizes the en masse refusal of dominantly situated knowers to enter into cooperative epistemic interdependence with non-dominantly situated knowers as both a structural and agential form of injustice.

${ }^{5}$ Mills (2007) introduces the notion of white ignorance, an actively maintained form of ignorance that masquerades as knowledge and forms the epistemological dimension of the racial contract of white supremacy. The racial contract of white supremacy prescribes and demands "white misunderstanding, misrepresentation, evasion, and selfdeception on matters related to race" (Mills 1997, 18). At the center of the false ideology of normative whiteness and eurocentrism is the white assumption that "we rule the world because we are superior; we are superior because we rule the world" (Mills 2007, 25). Such systemic white misunderstanding is not limited to the beliefs of white individuals. Rather, it characterizes the dominant mainstream worldview put forth by settler colonial epistemologies. White ignorance is an ignorance that is "propagated at the highest levels of the land, indeed presenting itself unblushingly as knowledge."

${ }^{6}$ Ruíz (forthcoming) writes, "Violence under colonialism is a deeper, cultural, epistemic, and discursive phenomenon that supports the internal consistency of colonial power by limiting the domain of intelligibility — what violence can appear as - to settler colonial logics."
} 
systems of colonial epistemology. Thus, the gaslighting at the heart of colonial genocides - and their corresponding epistemicides — is pre-structural, rather than merely structural. ${ }^{7}$

The colonial meta-epistemological framework that Ruíz identifies is just what is needed in order to make sense of white feminist methodologies and epistemology. Ruíz (forthcoming) notes, for instance, that Fricker's (2007) account of epistemic injustice depends for its intelligibility on a colonial epistemic framework that is capable of recognizing only certain subjects as knowers. Because of this dependence, white feminism remains what Ruíz (2019a) calls "a lifeline of colonialism." White feminism takes only a single-axis approach to genderbased oppression, ignoring the intersections of sexist oppression with racism, classism, ableism, cissexism, transphobia, heterosexism, homophobia, and national context. ${ }^{8}$ White feminism ignores both the existence of interlocking structures of oppression and how those structures of oppression are situated within and dependent on persisting structures of neo-colonialism and settler colonial violence. White feminism is not universal feminism, though it takes itself to be. As Young (2010) points out, white feminism paints itself as one-size-fits-all feminism when it in fact fits very few. White feminism does not present itself as feminism that applies only to particularly situated women, namely those are white, non-disabled, class-privileged, straight, cisgender citizens of 'Western' colonial and settler-colonial nation-states. Because white feminism fails to situate itself as applicable only in certain contexts and instead masquerades as universal, the underlying message of white feminism is that if it does not fit your lived experience, there must be something wrong with your experience, your interpretation of your experience, or your understanding of reality. This willful misrepresentation of the lack of fit between white feminism and the social-political realities it fails to reflect exemplifies the structural gaslighting at its core.

Feminist philosophy has a serious white feminism problem. This problem manifests in myriad ways, uncritically and unabashedly. Fricker's (2007) book is a representative case study of this problem. In what follows, I discuss the various ways in which Fricker's account of hermeneutical injustice engages in structural gaslighting. These include Fricker's use of a

\footnotetext{
${ }^{7}$ For a study of some aspects of the pre-structural gaslighting that was central to settler missionaries' colonial destruction of native Hawaiian epistemology and language, see Silva's (2004) detailed account of Kanaka Maoli resistance efforts to preserve Hawaiian epistemologies and genealogies in the face of organized, systematic setter efforts at epistemicide.

${ }^{8}$ While the phrases "white feminism" and "white feminist" are often misunderstood—such misunderstanding follows from interpreting the semantics of these phrases in a framework of compositionality: $\mathrm{x}$ is a white feminist if $\mathrm{x}$ is both white and a feminist - this is not how the phrase is generally used in works that critique white feminism. "White feminism" refers to a specific way of practicing feminism, to methodological practices of centering and decentering. Young (2010) explains, “'White feminism' is the feminism that doesn't understand western privilege, or cultural context. It is the feminism that doesn't consider race as a factor in the struggle for equality. White feminism is a set of beliefs that allows for the exclusion of issues that specifically affect women of color. It is 'one size-fits all' feminism, where middle class white women are the mold that others must fit. It is a method of practicing feminism, not an indictment of every individual white feminist, everywhere, always."
} 
whitewashed single-axis framework to theorize gender-based oppression, her narrative that a conceptual understanding of sexual harassment did not exist before a consciousness-raising group in the Cornell Human Affairs Program gave it a name, and her failure to recognize the historical legacies of women of color who have produced resistant epistemologies of sexual harassment and who are primarily responsible for public knowledge of this phenomenon. I argue that Fricker's whitewashing of the central roles that Black women and women of color have played in the legacy of epistemic resistance to sexual harassment in the U.S. is a form of structural gaslighting that fails to treat women of color as knowers, and this is a reflection of the colonial meta-epistemological commitments of white feminism.

\section{'Epistemic Bad Luck' or Structured Misinterpretation?}

Fricker's (2007) book is widely hailed as a path-breaking work of feminist epistemology that has paved the way for work at the intersection of epistemology and ethics. It has been extensively cited as offering a new framework for thinking about injustice and power dynamics within practices of knowledge production and distribution. It is also, in many ways, a perfect example of philosophy's white feminism problem. Fricker's work takes a single-axis approach to gender-based oppression and ignores women of color's contributions to the area she is writing in, effectively deeming the 1970 s the moment when workplace sexual harassment in the United States was first understood for what it was (2007, 162-63). Not only does she fail to think intersectionally about gender-based oppression but she fails to think structurally-even in a limited single-axis way_about oppression more generally.

Many of the methods and claims in Fricker's (2007) work function to produce gaslighting due to her outright denial of the role that oppression plays in producing structured misinterpretation and interpretive harm. ${ }^{9}$ Fricker casts as "epistemic bad luck" cases that she inaccurately construes as one-off instances of hermeneutical marginalization, but which actually have structural causes rooted in systems of domination. In her discussion of hermeneutical injustice, for instance she considers a fictional case of Joe, a straight white man who reports to the police that he is being stalked by another white man. When the police fail to take Joe's concerns seriously, Fricker describes the injustice Joe suffers as "thoroughly 'incidental' rather than systemic"' $(2016,8 ; 2007,158)$. She fails to recognize the role that rape culture and norms

\footnotetext{
9 These notions come from Ruíz's (2019) work on hermeneutic violence. Ruíz (forthcoming) offers a deeper critique of Fricker's framing of hermeneutic harms in terms of 'epistemic bad luck' based on the non-accidental nature of the colonial violence that was required in order for the register in which Fricker speaks to be legible in an epistemological landscape governed by cultural imperialism. She writes, "On this view, it is nonsensical to talk about epistemic 'bad luck' or accidental cases of hermeneutic injustice against people of color, unless, of course, one is operating under a settler colonial logic and supportive infrastructural economy."
} 
of toxic masculinity under cis-heteropatriarchy play in producing the interpretive harm that Joe experiences. Feminist theorists have long emphasized that, while straight men are not oppressed by patriarchy, they are nonetheless systemically harmed by it in a number of ways. One is the widespread myth that men cannot be the victims of sexual violence, stalking, or domestic abuse, either by women or non-binary people or by other men. These myths prevent Joe's reports of stalking from being audible and comprehensible to the police. Fricker's claim that straight men whose experiences of stalking are disbelieved by law enforcement suffer from incidental rather than systematic hermeneutical marginalization obscures the non-accidental relationships that these harmful myths bear to the structures of oppression that produce them and to the experiences they obscure. This is an instance of structural gaslighting that harms male victims of sexual violence. This is not a small demographic harm, as it conceptually undermines attempts to stem the global trafficking of male minors and male youth of color by concealing the forces responsible for both widespread first-responder and provider biases against male victims as well as the lack of advocacy and funding resources available to them (Cole 2018).

Fricker's explicit denial that structural factors play a role in obscuring knowledge about disability produces further structural gaslighting. Tremain (2016) critiques Fricker for claiming that the hermeneutical marginalization experienced by a person with an undiagnosed or poorly understood "medical condition affecting their social behavior" is not hermeneutical injustice but merely "a poignant case of circumstantial epistemic bad luck" $(2007,152)$. Fricker's denial of the structural nature of this interpretive harm exemplifies a pervasive pattern within dominant ableist ideologies wherein disabled people's experiences of ableism are dismissed as individual aberrations rather than as systematic, non-accidental, and reliably produced by structures of oppression. It further compounds the cumulative medical gaslighting that is widely experienced by disabled people by portraying medical gaslighting itself as a result of mere "epistemic bad luck" rather than as the predictable and enduring consequence of the medicalization of disability within a materially harmful and ableist system of medical meaning-making.

These are but a few of the myriad ways that Fricker's work exemplifies white feminist gaslighting by inaccurately and harmfully portraying structurally produced forms of hermeneutical marginalization as mere "epistemic bad luck." Fricker enacts structural gaslighting through her outright denial that the oppressive patterns of experience are structurally produced. Next, I consider structural gaslighting that follows from framing intersectional power dynamics as reducible to sexism and obscuring the histories of resistant epistemologies produced by women of color in Fricker's narrative of the conceptual history of sexual harassment.

\section{Interpretive Flatlining: Single-Axis Frameworks as Structurally Prejudiced Resources}


Not only does Fricker's work engage in structural gaslighting about the relationship of structures of oppression to one-off instances of injustice, it produces structural gaslighting through its refusal to engage or acknowledge hermeneutical resources produced by histories of epistemic resistance. As Dotson $(2012,2014)$ points out, injustice with respect to unfair credibility ascriptions, inadequate conceptual resources, and structurally biased epistemological systems has long been theorized and discussed in the work of women of color generally and of Black women specifically. ${ }^{10}$ Fricker entirely ignores these intellectual legacies in her work, and this is especially apparent in her discussion of hermeneutical injustice.

Hermeneutical injustice, according to Fricker (2007), occurs when there is a gap in the collective hermeneutical resources that leaves a marginalized group unable to understand or make sense of some aspect of their experience. Fricker illustrates the phenomenon by discussing Carmita Wood's experience, as recounted by Susan Brownmiller, of leaving a job due to sexual harassment before the concept of sexual harassment was widely known. As the story goes, Wood filed for unemployment after leaving a job at the Cornell Nuclear Physics Department because of recurring sexual harassment that took a toll on her mental and physical well-being. When Wood attempted to fill in the part of the unemployment application that asked the reason she left her job, none of the options on the form adequately captured the reason Wood left. Her only option was to say that she left for personal reasons. Fricker identifies the fact that she had no way to communicate the reason she left as an instance of hermeneutical injustice.

Fricker suggests that Wood had a large portion of her experience obscured from her understanding due to inadequate collective hermeneutical resources and that this fact is nonaccidental. Fricker writes:

"What women like Carmita Wood had to contend with at work was no plain epistemic bad luck, for it was no accident that their experience had been falling down the hermeneutical cracks." (Fricker 2007, 153)

It is certainly clear that the epistemic injustice described was "no plain epistemic bad luck." But there are two important questions to ask:

1) Who are "women like Carmita Wood?"

2) Why was it "no accident that their experience had been falling down the hermeneutical cracks?"

\footnotetext{
${ }^{10}$ See, for instance, Spillers (1984), Mohanty (1988), Spivak (1999), and Ortega (2006).
} 
Further, how does the answer to the first question inform the answer to the second? Fricker purports to analyze the structural prejudice in the shared hermeneutical resources that prevent "women like Carmita Wood" from identifying and understanding their experiences of sexual harassment in the workplace (99). ${ }^{11}$ Yet Fricker ignores the structural conditions that make certain groups of women, such as those who are Black, Latinx, poor and working-class, Indigenous, disabled, and without documented legal status among those who are most vulnerable to sexual harassment. This results in a flattened and whitewashed analysis of the relevant "structural identity prejudice" at play (155). In analyzing how social structures produce hermeneutical injustice with respect to sexual harassment, Fricker focuses solely on how the gap in the shared hermeneutical resources harms "women" and ignores the intersection of sexism with racism, ableism, citizenship, and economic vulnerability under capitalism. Fricker writes,

"Women's powerlessness meant that their social position was one of unequal hermeneutical participation, and something like this sort of inequality provides the crucial background condition for the epistemic injustice affecting Carmita Wood. $(2006,98 ; 2007,152)$.

Importantly, Fricker suggests that "something like" the unequal participation of women in producing hermeneutical resources is the crucial background condition for understanding the epistemic injustice experienced by victims of sexual harassment - not $a$ critical background condition. Fricker's choice to focus on Wood's experience as representative of the interpretive harms surrounding sexual harassment exemplifies May's (2012) observation that feminist theory remains wedded to the use of "gender-first imaginaries" despite the countless critiques levied against these gender-universalizing paradigms by women of color theorists.

\section{Naming and Power}

Not only does Fricker ignore the relevance of intersecting oppressions in creating the structural conditions that enable both workplace harassment and widespread misunderstanding of it, she ignores the legacies of understanding produced by Black women in the United States and by Indigenous and Latinx women on both sides of the settler border. Long before white women

\footnotetext{
${ }^{11}$ Various academic papers and news articles either explicitly refer to Carmita Wood as "African-American" (Backhouse 2012, 284) or imply that she is Black by including her in discussions of Black women's historic roles in resistance to sexual harassment in articles with such titles as "Sexual harassment law was shaped by the battles of Black women" (Lipsitz 2017), and "Women of color in low-wage jobs are being overlooked in the \#MeToo moment" (Lockhart 2017). An archives.com investigation of the 1940 U.S. census, however, reveals an entry under "Carmeta Dickerson," Wood's maiden name, containing her correct birthplace and listing her race as "White." Ambiguity about Wood's race aside, the problems with Fricker's framing of sexual harassment as an issue solely of gender-based sexism remain.
} 
activists such as Lin Farley led the meeting of the feminist consciousness-raising group to which Fricker attributes the origin of the concept of sexual harassment, Black women were speaking out about coercive sexual practices of the men they worked for. Despite this, Fricker ignores the entirety of Black women's resistant knowledge of sexual harassment just as she ignores the role of white supremacy, ableism, capitalism, and settler colonialism in producing the structural conditions for sexual harassment and the conceptual resources to understand it.

Fricker's methodology reveals a tacit commitment to the assumption that until a group of white women activists at Cornell University came up with the perfect phrase to describe the problem of sexual harassment, the phenomenon had gone not only unrecognized but untheorized. This mirrors Fricker's treatment of epistemic injustice as a concept that was philosophically untheorized and unexplored before her own engagement with it. ${ }^{12}$ In this section, I analyze some of the early resistant knowledge produced by U.S. Black women about the relationship among power, authority, and sexual harassment in order to demonstrate how Fricker's methodological assumptions and practices obscure Black women's knowledge production and produce structural gaslighting through situated ignorance and erasure.

As long as Black women in the U.S. have experienced sexual violence, they have engaged in interpretive practices of theorizing and resisting it. As Davis emphasizes, "Throughout the history of this country, Black women have manifested a collective consciousness of their sexual victimization" $(1983,183)$. Black women have been experiencing and theorizing sexual harassment at the hands of employers since long before white women entered the workforce in droves and became vulnerable to workplace harassment themselves. In his recorded work of Black American oral history, anthropologist John Gwaltney interviews Mabel Lincoln about her life experiences. Lincoln developed insight about the motivations for and practices of sexual coercion during her years of domestic work in white homes $(1993,68)$ :

"Now, if you are a woman slinging somebody else's hash and busting somebody else's suds or doing whatsoever you might do to keep yourself from being a tramp or a willing slave, you will be called out of your name and asked out of your clothes. In this world most people will take whatever they think you can give. It don't matter whether they

\footnotetext{
${ }^{12}$ It should be noted, for instance, that several decades prior to Fricker, Spillers (1984) identified a version of the problem of naming and existence, of absence and unreality that Fricker later attempted to christen "hermeneutical injustice.' In "Interstices: A Small Drama of Words," Spillers contemplates lexical gaps in the dominative mode of discourse where knowledge and understanding of Black women's sexuality should be. She further analyzes the structural conditions that give rise to a "lexical gap" in the universe of symbolic meaning regarding Black women's sexual agency. Fricker's concept of hermeneutical injustice is thus best understood as an example of what Davis (2018) terms epistemic appropriation.
} 
want it or not, whether they need it or not, or how wrong it is for them to ask for it. Most people figure, 'If I can get it out of you, then I am going to take it."'

Lincoln's analysis suggests a recognition that the desire to control and dominate tends to play a more central role than the desire for sexual pleasure in the motivation of sexual abusers. ${ }^{13}$ Nancy White, also interviewed by Gwaltney, is similarly aware that white men's sexual harassment of Black women is an abuse of power that is facilitated by impunity:

"White men were always messing with black girls. Sometime a black woman would have to move to someplace way away from there just so some white man or boy couldn't get his hands on her. Now, the white women saw this and they didn't like it, but they knew better than to stand up in Old Cracker's face and tell him that he was wrong. Now ... he knew he wasn't right, but he figured like this: If I want to do it and you can't stop me, well then, sad on you!” $(1993,146)$

A theme throughout much of the knowledge that White shares based on her experience of having "worked for money for more than sixty-four years" is that Black women often see the truth behind white men's oppressive actions in ways that white women choose not to. She describes white women as falling in line with what white men tell them so as not to jeopardize their standing within the power structure of white supremacy. Because white women wish to continue enjoying the benefits of their proximity to white male power, they know better "than to stand up in Old Cracker's face" and challenge his abuses of Black women. White is keenly aware of the situated and self-serving nature of white women's choices to refrain from challenging white male patriarchal power: ${ }^{14}$

"If that man was bringing me pretty hats and nice shoes and getting somebody like me to look after his children, now if he was doing all those things and I was too lazy to get up off my do-nothing-stool and content myself with what I could do for myself and my children, well if that was the kind of person I was, I'd just bite my lip and shut my mouth. Now that is your white woman."

\footnotetext{
${ }^{13}$ Second-wave white feminism often claims this insight for itself and frequently attributes it to Brownmiller (1975). This is another instance of whitewashing as structural gaslighting, as Black women have been theorizing the powerbased motivations for sexual violence since long before second-wave feminism existed.

${ }^{14}$ This is of central importance to explaining both the production of white feminist gaslighting and fact that the goal of white feminism is trying to gain equal standing for white women and white men under white supremacist capitalist patriarchy.
} 
White identifies a common form of motivated ignorance among white women. Her analysis of white women's allegiance to the hierarchy of white supremacist capitalist patriarchy and their commitment to refrain from challenging white male power thus extends into the epistemic realm. White women have a vested interest in falling in line with the perceptual and evaluative expectations that their white male companions impose on them:

"Some women, white women, can run their husbands lives for a while, but the most of them have to take low when the devil tells them to and they have to see what he tells them there is to see. If he tells them that they ain't seeing what they know they are seeing, then they have to just go on like it wasn't there!"' (149)

As White points out, white women's social position as white men's romantic partners and dependents has made them less likely to accurately identify white male harassing behavior as an intentional expression of power and domination. White women often fail to conceive of sexual harassment as a form of oppression and are taken in by gaslighting euphemisms for it such as 'harmless flirtation' in part because they are structurally invested in believing that white men are generally decent people who respect them as human beings. White women's confusion thus results from the vested interest they have in maintaining their active ignorance about white male patriarchal power in order to preserve their place in the white supremacist capitalist patriarchal hierarchy. ${ }^{15}$ As White emphasizes, "When you come right down to it, white women just think they are free. Black women know they ain't free. Now, this is the most important difference between the two" (Gwaltney 1993,147).

White's insights help to provide background for Fricker's assumption that Carmita Wood was confused by her sexual harassment and failed to understand it for what it was, as well as her assumption that Wood's harasser, Boyce McDaniel, may not have known or understood that his behavior was wrong. Wood's harasser had in fact tried to keep Wood from being hired in the first place and had waged a public campaign against her after his efforts failed. This suggests that McDaniel's sexual harassment and assault of Wood were acts of retaliation specifically intended to put her in her place. This background context casts doubt on Fricker's characterization of Wood's abuser as possibly not understanding the significance of his actions due to the purported hermeneutical lacuna in the collective conceptual resources. ${ }^{16}$

\footnotetext{
15 This gendered dimension to the epistemological system of white supremacy further demonstrates the importance of considering intersectional factors in theorizing the material conditions of epistemic domination. While Mills does not consider this aspect in his (2007) "White Ignorance," Frye identifies it in her (1983) essay "On Being White."

${ }^{16}$ That the abuser means to demean and humiliate the victim is a clear thread running through many women's experiences of harassment, and it has been especially salient to many Black women who have been harassed by white men. McDaniel was acting with impunity. The fact that Fricker attempts to secure the possibility of epistemic
} 
That Fricker makes the largely baseless claim that Wood did not truly understand the campaign of harassment that was being waged against her is further evidence of the insufficiency of Fricker's methodology and conceptual starting point. She writes, "It harmed Carmita Wood a great deal that she could not make adequate sense of it to herself, let alone to others" (2006, 103). She uses an ableist metaphor to construct Wood as suffering from a "cognitive disablement," which leaves her "deeply troubled, confused, and isolated" $(2007,151) \cdot{ }^{17}$ Fricker makes these claims about Wood's mental states without referring to any first-personal accounts of Wood discussing her experience. Rather than either interpreting Wood's experience and beliefs on the basis of her own testimony or refraining from speculating about her inner states altogether, Fricker relies on projections that Brownmiller makes of Wood's beliefs, emotions, and general psychological states.

While those who experience sexual harassment are sometimes unable to make sense of their own experience, Fricker should not presume this is what happened to Wood, especially as she fails to consider Wood's viewpoint as expressed in her own words. Dotson notes that people who are epistemically oppressed often have no difficulty readily articulating their experiences. "However, those articulations generally fail to gain appropriate uptake according to the biased hermeneutical resources utilized by the perceiver" $(2012,32) .{ }^{18}$ In Wood's case, it seems that she understood perfectly well what was happening to her but was prevented from conveying it meaningfully to those in positions of power, in part due to their willful ignorance. ${ }^{19}$

innocence-through-ignorance for a powerful white male assaulter who most likely knew exactly what he was doing throws into relief just how deep Fricker's investment in narratives of white innocence goes $(2007,151)$.

${ }^{17}$ This reference to "cognitive disablement" to characterize a lack of understanding is an instance of the systematically harmful ableist practice in the epistemologies of ignorance literature of using ableist metaphors to illustrate conditions of un-knowing. Tremain (2017, 31-32) critiques the role that "the continued institutionalization of ableist language in philosophical discourse" plays in the exclusion of both critical philosophies of disability from mainstream philosophy as well as the exclusion of disabled philosophers from the discipline. Tremain also challenges philosophers' reluctance and often outright unwillingness to give up these ableist practices, as exemplified for instance by Medina's (2013) defense of his use of blindness as a metaphor for ignorance. It should be uncontroversial that philosophers working in this area must find language to express and refer to ignorance that is not rooted in metaphors of disability.

${ }^{18}$ Pohlhaus $(2012,716)$ suggests that willful hermeneutical ignorance, the pervasive pattern in which dominantly situated knowers have access to epistemic resources created from the experiences of marginalized knowers but preemptively dismiss them and "continue to misunderstand and misinterpret the world" may be the more relevant concept here. Mason (2011) similarly critiques Fricker's assumption that Wood was unable to understand her own experience as well as her assumption that marginalized people rely solely on "collective" (i.e. dominant) hermeneutical resources in order to understand their experiences.

${ }^{19}$ In transcripts from her hearing, Wood described Boyce McDaniel as a "dirty old man" who frequently made "palpably sexual gestures" and treated women as "second-class citizens and inferior beings" (Baker 2007, 28). This suggests that Wood was perfectly able to recognize McDaniel's actions as intended to harm, degrade, embarrass, and terrorize her. She describes an episode at a company Christmas party in which he partially and forcibly disrobed her on the dancefloor, exposing her body to guests. Before leaving the job, Wood complained about McDaniel's treatment of her to his superior, but her complaints were dismissed. This further supports the interpretation that Wood had a clear understanding of what she was experiencing before she reached out to the Cornell Human Affairs Program for support and that she was simply ignored by those in a position to hold McDaniel accountable. 
The possibility that a victim of sexual harassment and assault might be able to understand the meaning of her abuser's violations, despite the lack of widespread knowledge of the concept 'sexual harassment,' would likely have seemed more plausible to Fricker if she had considered the long history of Black women's theorization of and resistance to sexual violence. Fricker's assumption that Carmita Wood could not understand her own experience of sexual harassment and assault results from an inadequate methodology that centers the experiences of relatively privileged white women, while ignoring the extensive conceptual work generated by Black women and women of color about sexual harassment. Fricker's centering of white women's experiences and conceptual practices leads to a theoretical framework that cannot adequately capture the phenomenon it aims to, even in the very limited cases that she actually considers.

Fricker's methodological oversights must be considered in light of what Dotson (2019) identifies as the ideational labor and aspirational costs of liberatory conceptual projects. For Dotson, ideational labor refers to "historical formations of ideas, concepts, and hermeneutic horizons that afford one conceptual and epistemic resources to direct and redirect attention." There is a collective responsibility to understand that any successful written project was made possible in part by the ideational labor of those who came before us. Readers must also attend to these facts lest we too become culpable for the erasure and epistemic appropriation of the ideational labor that produced the spaces of conceptual possibility we now inhabit.

\section{Structural Vulnerabilities}

By positioning Wood's experience as a paradigmatic case of sexual harassment in the workplace and analyzing it within a single-axis framework, Fricker whitewashes the picture of workplace harassment so that it may be universally relatable to 'all' women. ${ }^{20}$ Fricker's whitewashing functions as structural gaslighting, as her erasure of the roles of racism and settler colonialism in facilitating and producing workplace harassment upholds the myth that they are irrelevant to understanding both women of color's and Indigenous women's experiences of sexual harassment and the epistemic oppressions they face when seeking rectification. Her disregard for the role these factors play in producing workplace sexual harassment is not harmless, as it obscures the relationship between settler white supremacy and the non-accidental construction of the "hermeneutical lacuna" surrounding conceptual resources about sexual

\footnotetext{
${ }^{20}$ This universalizing move is characteristic of white feminist gaslighting. On Fricker's account, racism and colonization play no role in the structures of identity prejudice that obscure hermeneutical resources necessary to understand women's experiences of sexual harassment in the workplace. Fricker's whitewashing is an example of structurally biased hermeneutical resources being applied to a case for which far more suitable and fitting hermeneutical resources are already available. Such whitewashing therefore constitutes what Dotson (2012) calls contributory injustice.
} 
harassment. That settler colonialism and white supremacy depend for their persistence on the very form of active disappearing that Fricker's work generates reveals that a central function of white feminist gaslighting upholding white supremacist settler colonial domination.

It is not the result of accident or oversight that migrant farmworker women working in the U.S. without documented legal status are among those most vulnerable to sexual harassment, assault, and rape in the workplace. In a 2010 study, 80 percent of women farmworkers in California's Central Valley had experienced sexual harassment on the job (Waugh 2010). A report by Human Rights Watch (2012) reflects the pervasive and systemic nature of the sexual abuse that women farmworkers are subjected to: "Sexual violence and sexual harassment experienced by farmworkers is common enough that some farmworker women see these abuses as an unavoidable condition of agricultural work."

The structure of the farm hierarchy leaves foreman free to perpetrate abuse, and foremen often view the prospect of committing sexual violence against farmworker women as a perk of the job. They employ various strategies and methods to facilitate sexual violence, such as separating mothers from their daughters so that they have unhindered access to the children. The vast majority of supervisory positions are held by men (Waugh 2010). Many perpetrators hold directly supervisory roles over the women they harass, giving them consistent reason to be near the women they harass under the guise of checking their work. The harassment often continues over a long period of time, lasting for months or even years.

Workers who push back against or file formal complaints about the abuse routinely experience retaliation in the form of heightened abuse, reduced work schedules, or being fired. Multiple family members often work on the same farm, so retaliation is often directed at the victim's family members as well (Human Rights Watch 2012, 5). Extreme poverty and lack of other work possibilities often mean that staying in an abusive job is a matter of survival for farmworkers and their families. Farmworkers may also live in housing supplied by their employer, which means that losing their job would result in homelessness.

Indigenous women and girls are especially vulnerable to sexual and gender-based violence while working in the fields because of the cumulative, non-accidental structural vulnerabilities created and maintained by settler colonialism. For instance, since many Indigenous women do not speak English or Spanish, they are often unable to understand the content of trainings on workers' rights. California law, for instance, requires only that trainings be conducted in both English and Spanish, thus ignoring the needs of Indigenous workers who often speak only Zapotec, Mixtec, Triqui, or Nahuatl, for instance. Indigenous women who have been harassed or attacked are often unable to communicate it to government or law enforcement agencies that only recognize the legitimacy of settler languages. They also frequently distrust governmental and law enforcement agencies not only because of their consistently violent 
experiences with settler institutions, but because settler institutions are predicated on the entangled violences against their lands and bodies. The state-sponsored sexual violence that Indigenous migrant farmworkers face in the fields cannot even begin to be fully understood within the single-axis lens with which Fricker tries to analyze the "hermeneutical lacuna" surrounding “women's" experiences of sexual harassment in the workplace. The cumulative, non-accidental structural vulnerabilities created by ongoing processes of settler colonial violence and dispossession are essential to understanding not just the political and economic foreclosures that Indigenous women farmworkers face in settler societies but the epistemic ones as well.

Ruíz's decolonial account of structural violence provides a needed conceptual framework, as it contains the recognition that structural violence is never accidental (ms). Rather, the forms of violence that are perpetrated by settler administrative systems and their organizing logics inherently depend on what Ruíz refers to as settler epistemic economiescollections of hermeneutical resources specifically engineered to promote, uphold, and entrench colonial epistemic frameworks and forms of domination as the only possible epistemological systems and governance structures while violently foreclosing on alternative epistemologies. Her account not only helps to reveal the colonizing function of the 'omission' of on-the-job labor rights training offered in Indigenous languages. It also shows why Fricker's concept of hermeneutical injustice is rendered dead-on-arrival as an interpretive resource that might be able to shed light on the epistemic brick walls that Indigenous women farmworkers collide with when attempting to speak and be heard about the pervasive non-accidental sexual harassment they experience while working on stolen lands under a settler colonial capitalist governance structure.

Just as the reasons that Indigenous women farmworkers are subject to pervasive sexual harassment while working in agricultural economies north of the settler U.S.-Mexico border are non-accidental, specific histories and structural conditions have also made Black women in the settler colonial United States non-accidentally vulnerable to sexual violence by those on whom their lives and livelihoods have depended. As Nancy White's and Mabel Lincoln's insights show, U.S. Black women's social locations within white supremacist capitalist patriarchy are also essential to understanding both their experiences of sexual harassment by abusive employers and colleagues and their resistant practices of theorization in the face of racist sexual oppression.

Historical structures of oppression bear a non-accidental relationship to contemporary conditions of vulnerability to workplace sexual harassment. Under slavery, white enslavers systematically used sexual violence against enslaved Black women both as a form of control and domination and as a tool of wealth production. White enslavers not only treated Black women as property, they treated their bodies as units of capital capable of producing additional units of capital (Davis 1983, King 1988, Collins 2000). This resulted in a social structure that was held in 
place as much by sexual violence as it was by other forms of physical punishment and psychological torture:

Slavery relied as much on routine sexual abuse as it relied on the whip and the lash. Excessive sex urges, whether they existed among individual white men or not, had nothing to do with this virtual institutionalization of rape. Sexual coercion was, rather, an essential dimension of the social relations between slavemaster and slave. In other words, the right claimed by slaveowners over the bodies of female slaves was a direct expression of their presumed property rights over Black people as a whole. The license to rape emanated from and facilitated the ruthless economic domination that was the gruesome hallmark of slavery. (Davis 1983, 175)

This violent domination of Black women's bodies created a lasting legacy of white and statesponsored coercive control over Black women's fertility and reproduction (Roberts 1997). The controlling image of Black women as hypersexual, promiscuous, and sexually available was developed under slavery to justify white enslavers' systematic use of rape as a mechanism of terror and subordination. It continues to govern (white) conceptions of Black female sexuality and is one of the many factors that both contributes to and obscures the high rates of sexual violence that Black women experience today.

After slavery was abolished, the work opportunities available to Black women remained primarily limited to those tasks that were assigned to them under slavery (Collins 2000, 60-63). According to Davis $(1983,175)$, the 1940 U.S. census showed that 59.5 percent of employed Black women worked as domestic servants and only 10.4 percent worked in non-domestic service occupations. Black women who worked in the homes of white families faced the constant threat of sexual harassment and sexual assault by their employers. White domestic employers treated Black women with an impunity they enjoyed as the result of the limited work available to them. The professional standards to which white employers held Black domestic workers were often characterized by deference and obedience rather than by domestic skill. ${ }^{21}$ These relations of domination and subordination enforced the idea that Black women existed in white homes as objects of control subject to the whims of their white employers, and this created optimal conditions for workplace sexual harassment and assault to flourish.

\footnotetext{
${ }^{21}$ Employer-employee relationships were marked by efforts to demean workers and remind them of their place in the classed, raced, and gendered social hierarchy. Norms establishing this included requiring workers to wear uniforms in the home, addressing workers as "girls," restricting workers' movements through the house, and speaking as though they were not present (Collins 2000).
} 
Today, the service labor that has characterized much of the work delegated to Black women under white supremacist capitalist patriarchy has moved into the public sphere. Whereas most paid cooking and cleaning work used to take place in the private homes of white families, it is now performed as food service and janitorial labor for public corporations (Collins 2000, 69). ${ }^{22}$ As the labor that Black women traditionally perform has moved out of the domestic sphere and into the open, so too has the workplace sexual harassment to which Black women are subjected. The mistreatment that Black women face from those they encounter in the workplace "resembles the interpersonal relations of domination reminiscent of domestic work" (62).

The precarity of Black women's paid labor further exacerbates their vulnerability to workplace abuses. Black women are overrepresented in low-paying and minimum-wage jobs, tipped positions, positions without benefits, and temporary positions with high rates of turnover. Not only is sexual harassment a stable feature of service-industry jobs, labor abuses such as wage theft are also rampant in this sector (Wohl 2014, Bobo 2010, Greenhouse 2009). These factors all contribute to the state of affairs in the contemporary United States in which Black women have little wealth, especially in later life, and significantly less wealth than white women (Chang 2010, Brown 2012). These economic factors together create circumstances under which Black women are less able to leave jobs in which they are subject to sexual abuse, which in turn makes Black women more susceptible to becoming targets for sexual abusers in the workplace.

\section{Controlling Images and Dominating Mythologies}

The effects of structural oppression and colonization cannot be understood without their justifying ideological dimensions and the epistemic functions they fulfill. No understanding of the "dominating mythologies" that both produce and obscure male sexual violence against Black women can be accomplished without an intersectional analysis that attends to the role of racism in sexual harassment (Spillers 1984, 158). Just as the realities of sexual harassment in the workplace are importantly different for women of color and white women, so too are the hermeneutical resources used to justify it. Controlling images of white women's sexuality under white supremacist patriarchy differ, for instance, from those governing Black women's sexuality. White women are portrayed as fragile and in need of protection, in ways that are often linked to their presumed chastity, virtue, and innocence. Black women, on the other hand, have tended to be portrayed as promiscuous, sexually insatiable, and animalistic in their sexuality (Collins 2000,

\footnotetext{
${ }^{22}$ Collins writes, "The work performed by employed poor black women resembles duties long associated with domestic service. During prior eras, domestic service was confined to private households. In contrast, contemporary cooking, cleaning, nursing, and child care have been routinized and decentralized in an array of fast food restaurants, cleaning services, day-care centers, and service establishments. The locations may have changed, but the work has not" $(2000,69)$.
} 
2005; Roberts 1997). These symbolic productions all take place within a conceptual landscape that withholds ascriptions of sexual agency from Black women. As Spillers writes, "In the universe of unreality and exaggeration, the black female is, if anything, a creature of sex, but sexuality touches her nowhere." (Spillers 1984, 115)

The images of masculinization and deviant hyper-sexuality that have characterized representations of Black womanhood under white supremacist capitalist patriarchy have provided a foil against which white women's femininity and fragile womanhood have been constructed (Carby 1982). In the 1800s, Sarah Baartman's body became a site of projection for the colonial fantasy that would eventually employ theories of scientific racism to delineate the borderline between the 'abnormal African' woman and 'normal European' woman. ${ }^{23}$ As Carby notes, "Our continuing struggle with History began with its 'discovery' of us" $(1982,110)$. Baartman, a Khoikhoi woman born in what is now South Africa, was brought to England and later France where she was displayed in a loin cloth to prurient European audiences who marveled at the size and shape of her breasts and buttocks. After her death, Georges Cuvier dissected her body and used it as a basis for his theories of scientific racism and sexual primitivism. Despite the fact that Baartman had never allowed audiences to see her naked, Paris's Musée de l'Homme displayed her jarred remains, including her skeleton, brain, and vulva to the public until 1974 - a grotesque manifestation of white colonial society's sense of entitlement to and ownership of Black women's bodies. ${ }^{24}$

White entitlement to Black women's bodies is a central feature of the controlling image of the Jezebel, which continues to govern popular imaginaries of Black female sexuality today. Crenshaw $(1994,3)$ identifies some of the measurable effects of the widely-held misogynoiristic notion that Black women and girls are hypersexual: "As recently as 1989, jurors acquitted a defendant of the rape of a 12-year-old African American stating that 'a girl that age from that neighborhood probably wasn't a virgin anyway." ${ }^{25}$ Part of the function of the controlling image as hermeneutical resource is to produce high rates of sexual violence against Black women while simultaneously obscuring its pervasiveness and foreclosing the possibility of redress for it.

As a powerful tool in what Spillers $(1984,167)$ identifies as the "universe of symbolmaking" regarding Black women's sexuality, the Jezebel image also governs the treatment of Black women by both white women and white men. Cottom (2013) describes an experience in a

\footnotetext{
${ }^{23}$ Scientific racists treated the presumed physical differences between Baartman and 'European' women as proof of the savageness, deviant sexuality, and promiscuity of the 'African race.'

${ }^{24}$ Nelson Mandela demanded the repatriation of her remains in 1994. They were not returned to South Africa to be buried until 2002.

${ }^{25}$ She goes on, "A recent study in Dallas revealed that the average sentence given to the rapist of a Black woman was two years ... Interviews with jurors reveal that the low conviction rate of men accused of raping Black women is based on ongoing sexual stereotypes about Black women.”
} 
bar in North Carolina where she told her date that one of the drunk white couples there would be offering her free liquor and attempting to feel her breasts "within the hour." She explained her "long, storied, documented history of being accosted by drunk white men and women in atmospheres just like these." 26 Eventually, a white woman "bumps and grinds" up to their table, buys them a fishbowl, and tells Cottom that her boyfriend would love to see them dance together. Cottom directly relates her experiences to controlling images that portray Black women, especially those with larger bodies, as always interested in and available for sex. She writes, "Fat non-normative black female bodies are kith and kin with historical caricatures of black women as work sites, production units, subjects of victimless sexual crimes, and embodied deviance." As Cottom's experience and her analysis of it show, the Jezebel controlling image remains central to the logic of white supremacist capitalist patriarchy that facilitates white entitlement to access and control Black women's bodies.

The pervasive and pernicious nature of this controlling image is by no means limited to the conservative American South; it also dominates the white liberal cultural imaginary. In 2016, white American author Stephen O'Connor published a novel called Thomas Jefferson Dreams of Sally Hemings, which explores the 'romance' between Jefferson, a white male enslaver 'founding father' and Hemings, a Black girl child whom Jefferson enslaved and repeatedly raped. In a book review published by NPR, Jean Zimmerman (2016) describes the work as "the agonizing crashing together of love and slavery." Zimmerman uncritically quotes O'Connor's own assessment of the relationship as "somewhere along the spectrum between love and Stockholm syndrome." She writes:

"Though Jefferson was 46 when he bedded 16-year-old, lovely, yellow-silk-clad Sally at his grand hotel, we see a passion between them. The entire book revolves around the issue of consent - to what degree Sally determines her own fate with her master or whether she's being forced, whether freedom to say no rather than yes could ever be a possibility for an enslaved female, a child at that."

It is deeply indicative of the ideology that attempts to locate pathological carnal desire in the bodies of Black women and girls that Zimmerman finds herself able to ask the question of whether an enslaved girl child can consent to sex with her adult male enslaver.

\footnotetext{
${ }^{26}$ Cottom catalogues some of the incidents of harassment she's experienced in such settings: "Women asking to feel my breasts in the ladies' restroom. Men asking me for a threesome as his drunk girlfriend or wife looks on smiling. Frat boys offering me cash to 'motorboat' my cleavage. Country boys in cowboy hats attempting to impress his buddies by grinding on my ass to an Outkast music set. It's almost legend among my friends who have witnessed it countless times."
} 
The answer, of course, is no. Hemings did not have "the freedom to say no rather than yes," as her very survival depended on her not saying no. The possibility of saying 'no' without punishment is a necessary condition on consent's being freely given, on saying 'yes' having any meaning at all. This was not a possibility for Hemings, who was owned as property by an enslaver who created a political system specifically to be able to enslave, rape, torture, and kill human beings like her with impunity. Nonetheless, O'Connor finds this subject matter to be fitting material for a romantic narrative and Zimmerman is happy to enter his fantasy world with him. It is difficult to understand how these imaginative feats and conceptual contortions could be possible for them unless they both, on some level, conceive of Black women and girls as unrapeable. To see the possibility of freely given consent in the context of chattel slavery-a scenario in which there so clearly is none-is to see Black women and girls as incapable of being victims of sexual violence. This example reveals how effective the violent ideology of the Jezebel remains today.

The influence of assumptions about Black women's sexuality, promiscuity, and fertility continues to contribute to widespread harm, abuse, and violence. The legacy of slavery continues to shape U.S. Black women's contemporary experiences of sexual harassment in the workplace. Historical patterns of sexual coercion and white (especially male) sexual entitlement to Black women's bodies continue to construct the conceptual landscape that allows for unconstrained sexual violence against Black women. A white feminist approach to the hermeneutics of sexual harassment contributes to the "structure of unreality" that Black women face in the shared conceptual landscapes of white supremacist capitalist patriarchy, a vacuum that is filled by controlling images. This is not, as Spillers notes, a harmless omission. She writes, "The rift translates into unthinkable acts, unspeakable practices" (Spillers 1984, 156). White feminist epistemology is complicit in sexual violence against Black women insofar as it works to maintain conceptual systems that continue to obscure such violence.

Fricker's framing of the structural conditions that produce hermeneutical injustice surrounding sexual harassment in terms of "women's powerlessness" is a devastatingly inadequate conceptual framework for the problem at hand. Fricker's misuse of conceptual resources obscures the role that white supremacist capitalist patriarchy plays in producing and protecting practices of sexual harassment against Black women specifically and women of color more generally. Lest epistemic harms be mistaken for disembodied ones, the "unthinkable acts" to which Spillers refers, the ones that are facilitated by the epistemic rift that Fricker is complicit in maintaining, are acts that take place in the material world and that are borne upon the bodies of human beings. Taking an intersectional approach to mapping the conceptual landscape of sexual harassment in the workplace instead of a white feminist one is thus not merely a methodological imperative, it is an ethical one. 


\section{Women of Color's Resistance to Sexual Harassment}

Women of color in the U.S. have historically been at the forefront of resistance to sexual harassment through both litigation and labor organization. Epistemic resistance to oppression cannot be considered independently from activism and organized resistance. The work of Black, Latinx, and Indigenous women labor organizers like Floria Pinkney, Lucy Parsons, Maria Moreno, Dolores Huerta, and Luisa Moreno has been essential to publicly revealing the ways that the systems of gender domination that produce sexual harassment are inextricably bound up with systems of racism, colonialism, and capitalist labor exploitation. Women of color have long recognized that the ability to be free from sexual assault in the workplace cannot be disentangled from systemic barriers to fair wages, labor protections, housing, education, food access, health care, and immigration. Catherine Albisa, co-founder and Executive Director of National Economic \& Social Rights Initiative explains, "While counterintuitive, you can't end genderbased violence by working directly on gender-based violence. You can only end gender-based violence by working on structural issues that enable it, and those also shape the wider array of abuses affecting the whole community" (Chang 2018).

This insight remains at the core of the Fair Food Program, one of the most productive and effective large-scale efforts to reduce workplace sexual harassment in the United States today. Started in the early 2000s by the Coalition of Immokalee Workers, the program works by securing agreements from major companies such as Walmart, McDonald's, and Yum! Brand Foods to only purchase produce from farms who have signed on to a strict code of conduct, drafted by farmworkers, requiring a variety of fairer labor practices including zero tolerance for sexual assault (Fair Food 2017). This work is structurally re-shaping the landscape of agricultural work in the United States, and it is made possible by the conceptual and epistemic resistance work done by migrant farmworker women to reveal the ways that sexual harassment is predictably facilitated by interlocking systems of power, control, and domination.

Women of color's diverse positionalities are non-accidentally related to the strategies of epistemic resistance they have created. As Collins $(2000,15)$ notes, for instance, since Black women in the U.S. have experienced continued political exclusion, ideological marginalization, and economic vulnerability, these factors and others give rise to "distinctive angles of vision" on their experiences and the structures that produce them. It is thus not surprising that Black women plaintiffs were among the first to conceive of sexual harassment as illegal sex discrimination. ${ }^{27}$

\footnotetext{
${ }^{27}$ Baker $(2004,8)$ writes, "Racist and sexist stereotypes melded in the harassment directed toward African American women, giving them a particularly clear understanding of the discriminatory nature of sexual overtures in the
} 
Pamela Price, one of the student plaintiffs in the first case to establish that sexual harassment was sex discrimination and thus illegal under Title IX, recognized the role that racist sexist ideology about Black women played in her harasser's actions. After experiencing sexual harassment from a white male professor at Yale University who retaliated against her when she refused his requests for sex, Price saw that historically developed controlling images of Black women's sexuality played a central role in the harassment she experienced. Noting that her harasser invoked racist tropes in his sexually humiliating comments toward her, Price characterized her experience of harassment as an instance of "racist sexual discrimination" and argued that her professor retaliated against her as punishment for failing to live up to "a historical conception of the relationship between my racial heritage and my sexuality" (Baker 2007, 61). Price's ability to clearly conceive of how her professor had violated and harmed her was integral to her pursuit of legal action that led to the establishment of one of the most important precedents for university students, namely that those who experienced sexual harassment in educational institutions could sue the school under Title IX for monetary damages.

Sexual harassment law is similarly indebted to trailblazing Black women plaintiffs like Diane Williams, Paulette Barnes, Mechelle Vinson, Sandra Bundy, and Anita Hill. ${ }^{28}$ These women's efforts to publicly resist their experiences of sexual harassment through the courts (and televised Senate hearings) not only brought the problem into public awareness but radically changed the legal and conceptual landscape surrounding sexual harassment, which was previously characterized as an individualized, private, and personal transgression and therefore not governed by laws regulating employment discrimination. These women worked to create new epistemological frameworks in the legal sphere, and the innovation they produced cannot be severed from their distinctive angles of vision.

Fricker's failure to situate her analysis of the epistemic activism by Cornell feminists within this history is one instance of the larger pattern of white feminist indifference to women of color's experiences of harassment and their practices of resistance to it. Focusing solely on the epistemic resistance work produced by the white women in the Cornell Human Affairs Program

workplace. Informed by a history of race discrimination and sexual abuse, these women did not mistake sexual harassment for harmless flirtation."

${ }^{28}$ Diane Williams brought the first successful lawsuit against an employer who retaliated and ultimately fired her after she repeatedly denied his harassing advances. Her case, Williams vs. Saxbe was decided in 1976 and was the first to set a precedent of sexual harassment as an employment-related, gender-based civil rights violation (Baker 2007, 21). In 1978, Mechelle Vinson filed a lawsuit against the bank where she worked after her manager had repeatedly raped her under threat of firing her. Her case Meritor Savings Bank v. Vinson went to the Supreme Court, and in 1986, the Court ruled that a company can be held responsible for a supervisor's harassment even if the company was unaware of it. In the Court's decision, Justice William H. Rehnquist wrote, "Without question when a supervisor sexually harasses a subordinate because of the subordinate's sex, the supervisor discriminates on the basis of sex" (Brown 2017). Vinson's case thus became the first to successfully use Title VII in a Supreme Court case on sexual harassment, establishing that sexual harassment was discrimination on the basis of sex and thus prohibited by law. 
is whitewashing. Fricker engages in this whitewashing by failing to address the central role that Black women played in litigating some of the first and most important cases of sexual harassment in the U.S. and by ignoring the knowledge that women of color labor activists created surrounding the interlocking nature of systems that produced the conditions for capitalist exploitation and extractivism to thrive alongside the violation of women's bodies. Attending to these women's resistance efforts should have been essential to Fricker's project since their efforts were characterized in significant part by their methods of epistemic resistance. Fricker's failure to recognize the conceptual work produced by women of color who recognized sexual harassment in the workplace as a form of coercion and discrimination is a failure to consider their agency and resistance in the face of oppression. By failing to situate the work of the Cornell consciousness-raising group within the broader context of women of color's resistance to sexual harassment, and by ignoring women of color's conceptual contributions to this history of resistant interpretive practices, Fricker demonstrates a more general failure to conceive of women of color as knowledge creators.

\section{Situated White Feminist Ignorance As Willful Ignorance}

"Contributory injustice occurs because there are different hermeneutical resources that the perceiver could utilize besides structurally prejudiced hermeneutical resources, and the perceiver willfully refuses 'to acknowledge and acquire the necessary tools for knowing whole parts of the world." - Dotson $(2012,32)$

Dotson (2012) identifies contributory injustice as a third-order form of epistemic injustice - one that Fricker (2007) not only fails to account for but engages in herself. Contributory injustice occurs when the hermeneutical resources necessary for marginalized knowers to understand their experience are available, but there are structural biases against their use. Someone commits contributory injustice when their situated ignorance in the form of willful hermeneutical ignorance causes them to use the wrong set of hermeneutical resources, harming a knower's epistemic agency in the process. Like willful hermeneutical injustice, contributory injustice is both structural and agential. It is structural because the biases that cause certain sets of hermeneutical resources to be seen as coherent and intelligible are both a result and continued cause of structural domination. It is agential because the epistemic harm is caused by an agent's situated ignorance in the form of willful hermeneutical ignorance.

By employing a single-axis framework of sexist oppression to analyze sexual harassment in the workplace and by ignoring the historical legacies of women of color's epistemic resistance to it, Fricker uses structurally prejudiced hermeneutical resources at every turn in her analysis of 
hermeneutical injustice. Fricker's use of these resources can be reliably predicted from her social location, and thus follows from her situated ignorance. ${ }^{29}$

Fricker's ignorance is not only situated and reliable, it is also willful. Fricker chooses not to acknowledge, for instance, the part of the world in which Black women's experiences of sexism are racialized and the racism Black women face is gendered. Fricker willfully refuses to acknowledge the ways that race- and class-based oppression intersect with sexism and misogyny to produce especially harmful outcomes for working-class women of color. ${ }^{30}$ When she engages with issues of anti-Black racism, she focuses solely on examples that primarily affect Black men. ${ }^{31}$ She does not explicitly discuss experiences of racism faced by Black women or nonBlack women of color. When she does discuss forms of discrimination that Black women do face, such as sexual harassment in the workplace, she leaves racism entirely out of her analysis of the structural forces that produce it.

Further evidence for the claim that Fricker's ignorance is not merely situated but also willful is that many white women who have written about sexual harassment have actually acknowledged the epistemic significance of the fact that so many of the early plaintiffs in sexual harassment cases were Black women and women of color. Catherine Mackinnon (1979), for instance, who helped write Mechelle Vinson's appellate brief for the Supreme Court, connects Black women's marginalization with their pathbreaking efforts to resist harassment. ${ }^{32}$ That Mackinnon recognizes that the multiple jeopardies that Black women face in U.S. society create

\footnotetext{
${ }^{29}$ Dotson (2011) characterizes situated ignorance as follows: "Situated ignorance follows from one's social position and/or epistemic location with respect to some domain of knowledge. It is an 'unknowing' that is prompted by social positioning that fosters significant epistemic differences among diverse groups." (248)

${ }^{30}$ Fricker also refuses to acquire the tools necessary to learn about these parts of the world. She does not, for instance, cite the work of any Black women in her (2007) book that claims to introduce the concept of epistemic injustice, nor does she cite the work of any women of color outside academic philosophy. This is especially significant given that, by the time she published her (2007) book, women of color theorists had already conceptualized complex aspects of the phenomena that Fricker would later call testimonial injustice and hermeneutical injustice (See, for instance, Carby 1982; Spillers 1984; Mohanty 1988; Spivak 1999; Collins 2000, 2005).

${ }^{31}$ These include Britain's "cultural forgetting of the involvement of black Caribbean and African soldiers in the Second World War" (Fricker 2016, 14-17) and a fictional instance of a white woman falsely accusing a Black man of rape from the novel To Kill a Mockingbird. It is worth asking why Fricker (2007) chooses to focus on a fictional example rather than on any of the numerous actual occurrences of this phenomenon, especially given that she does not situate the fictional instance within U.S. white supremacy's epidemic of lynching. She also fails to recognize the fact that the most common justifications for the lynching of Black men were baseless allegations that they had raped a white woman (Wells-Barnett 1900) - something that forms the central narrative arc in the fiction she uses to exemplify testimonial injustice.

32 She writes, "Black women's least advantaged position within the economy is consistent with their advanced position on the point of resistance. Of all women, they are most vulnerable to sexual harassment, both because of the image of black women as the most sexually accessible and because they are most economically at risk. These conditions promote black women's resistance to sexual harassment and their identification of it for what it is." $(1979,53)$
} 
the possibility of distinctive angles of vision on the interlocking systems of oppression they exist within suggests that occupying a social position that gives rise to situated ignorance is not sufficient for maintaining it.

Further, Fricker actually engages with the work of white women feminist theorists who recognize and discuss the structural importance of racism and other dimensions of oppression when it comes to understanding sexual harassment. In her (1999) memoir, on which Fricker relies heavily, Brownmiller connects the intersectional oppression of women of color to their positions on the frontlines of resistance. She recognizes that the number of high-profile sexual harassment litigants who were Black women was non-accidental. Brownmiller connects the social realities of women of color and queer women to their epistemic positions that allowed them to clearly identify sexual harassment as harmful and wrong despite widespread interpretive efforts to paint it as complimentary or trivial. ${ }^{33}$ Brownmiller recognizes not only that differences in social location are relevant to experiences of sexual harassment but that such differences are relevant to the creation of knowledge about these experiences and their relationship to structural domination.

Perhaps the most significant evidence that Fricker's ignorance is willful is the fact that Brownmiller's (1999) discussion of this topic appears in the very same chapter from which Fricker draws her discussion of Carmita Wood's experience. Though Brownmiller discusses the non-accidental nature of Black women's epistemic insights regarding sexual harassment in the very work that Fricker cites, Fricker chooses not to acknowledge racist or capitalist oppression in her explanation of "the background conditions that were conducive to the relevant hermeneutical lacuna" surrounding sexual harassment $(2007,152)$. That this section appears between two of the passages that Fricker quotes in her own work suggests that Fricker was likely aware of the racial and economic dimensions of sexual harassment cases in the United States but nonetheless chose not to include them in her (2007) work. Thus, in her discussion of why it was "no accident" that the experiences of "women like Carmita Wood" "had been falling down the hermeneutical cracks," (2007, 153) it was also no accident that Fricker let important aspects of other women's sexual harassment experiences slip through the hermeneutical cracks of an interpretive

\footnotetext{
${ }^{33}$ Brownmiller writes, "Adrienne Tomkins happened to be white, but most of the aggrieved women seeking justice in these and other pioneer cases were working class and black. . . Black women were significant at every stage in sexual harassment law. It's interesting to speculate why so many of the courageous litigants were women of color, just as it's interesting to ponder the significance of lesbian feminist leadership in the naming and launching of sexual harassment. I'm inclined to believe that neither phenomenon was totally accidental. I believe lesbian feminists, the angriest of the angry, initially saw unwanted sexual attention by men with greater clarity than their heterosexual sisters and were less of a mind to be persuaded that it was vaguely complimentary or basically trivial. And black women, emerging from a history of slavery, segregation, job discrimination, and sexual abuse, were fighting mad. Doors were beginning to open for them, and then, bam, the same old story, opportunity turning to ashes. The success of race discrimination complaints during this time may have encouraged women of color to pursue their rights in cases of sexual harassment" (1999, 286-7).
} 
framework that she herself designed. This reveals the legacy of structural gaslighting in white feminist epistemology.

\section{Beyond 'Strategic Forgetting'}

Feminist epistemology that aims to be liberatory must work to create practices of critical and collective self-reflection. White feminist philosophy's shortage of such practices is evident in its persistent reliance on what Tompkins (2016) calls "strategic forgetting"- a white feminist methodology that is especially apparent in Fricker's work:

"The narrative of apparent progress embedded in the teaching of feminist theory often rests on some very strategic forgetting, usually of the work of women of color, in particular black women. Ultimately the 'what about' question is often answered with some blunt historical facts: $\mathrm{X}$ was speaking all along, over here, where other people were listening, stealing and forgetting to footnote." (Tompkins 2016)

Such strategic forgetting is a primary mechanism of structural gaslighting, but its effects reach well beyond those who pay the price with their own felt knowledge. In many ways, Fricker's work has set the terms of the debate in contemporary feminist epistemology. The conceptual landscape that she has constructed - along with its glaring structural absences, erasures, and disappearances - is now construed as the common ground. It forms the epistemic field upon which fair play is imagined to take place. The question then becomes: what to do about the sad state of this field? It is unquestionable that white feminist theory has been built on a foundation of simultaneously ignoring and stealing the theoretical work of women of color and Native feminist theorists. But it does not follow that mere 'inclusion' and 'recognition' of these perspectives within existing settler colonial white feminist frameworks offers a solution (Arvin, Tuck, and Morrill 2013). ${ }^{34}$ As Tompkins emphasizes, a radical reframe is needed to adequately address the issue of perspectives that have 'gone missing' in white feminist theoretical frameworks:

Often we are tempted to ask the "what about" question: e.g., what about the people who are excluded from this theory? Although not an unreasonable question, asked in this

\footnotetext{
${ }^{34}$ As Arvin, Tuck, and Morrill $(2013,17)$ emphasize, "It is important for feminist discourses to determine ways to engage Native feminist theories and the experiential realities of Indigenous women-identified people without absorbing or merely including them into the existing canon of gender and women's studies literature. . . The project of inclusion can serve to control and absorb dissent rather than allow institutions like feminism and the nation-state to be radically transformed by differing perspectives and goals."
} 
manner this is not really a sophisticated question because it doesn't open up conversation. The only answer to "what about" is: they aren't there. More productive is to ask: how do the exclusions at the heart of this work facilitate certain conclusions, problems or paradigms, what are these paradigms and what happens when we consider this theory in a broader context?

The epistemic exclusions at the heart of white feminist philosophy facilitate paradigms that can no longer be allowed to persist. There are a multitude of diverse theoretical frameworks and epistemologies upon whose active disappearing the conceptual foundations of white feminist philosophical schemas are predicated. If something like epistemic justice is a goal of feminist epistemology, then feminist philosophy must work to dismantle and replace epistemic institutions built on conceptual foundations of white supremacy and colonialism. This requires much more than just plugging up the "hermeneutical lacunae" that remain within existing epistemologies of domination. It requires an exercise of courage and accountability that cannot coexist with the instinct to preserve white innocence and blamelessness that drives so much of white feminist discourse. Whether white women working in feminist theory are willing rise to this challenge remains to be seen.

Acknowledgements: Thank you to Kristie Dotson and Elena Ruíz for their wisdom and generous guidance on this work. Thank you also to audiences at the Claremont McKenna Gaslighting and Epistemic Injustice Conference, the Society for Analytical Feminism Session at the 2017 Pacific APA, and the 10-year Celebration for the Department of Literature, Philosophy, and The Arts at the University of Michigan-Dearborn.

\section{References}

Arvin, Maile, Eve Tuck, and Angie Morrill. 2013. Decolonizing feminism: Challenging connections between settler colonialism and heteropatriarchy. Feminist Formations 25 (1): 8-34.

Backhouse, Constance. 2012. Sexual harassment: A feminist phrase that transformed the workplace. Canadian Journal of Women and the Law 24 (2): 275-300.

Baker, Carrie. 2004. Race, class, and sexual harassment in the 1970s. Feminist Studies 
30 (1): 7-27.

Baker, Carrie. 2007. The women's movement against sexual harassment. New York: Cambridge University Press.

Bobo, Kimberly. 2010. Wage theft in America: Why millions of working Americans are not getting paid - and what we can do about it. New York: The New Press.

Brown, DeNeen L. Oct 13 2017. She said her boss raped her in a bank vault. Her sexual harassment would make legal history. The Washington Post. https://www.washingtonpost.com/news/retropolis/wp/2017/10/13/she-said-her-bossraped-her-in-a-bank-vault-her-sexual-harassment-case-would-make-legal-history/

Brown, Tyson. 2012. The intersection and accumulation of racial and gender inequality: Black women's wealth trajectories. The Review of Black Political Economy 39 (2): 239-258. https://doi.org/10.1007/s12114-011-9100-8

Brownmiller, Susan. 1999. In our time: memoir of a revolution. New York: Dial Press.

Brownmiller, Susan. 1975. Against our will: men, women, and rape. New York: Random House.

Carby, Hazel 1982. White woman listen! Black feminism and the boundaries of sisterhood, in The Empire strikes back: race and racism in 70s Britain, ed. The Centre for Contemporary Cultural Studies. London: Hutchinson.

Chang, Mariko Lin. 2010. Shortchanged: why women have less wealth and what can be done about it. New York: Oxford University Press.

Chang, Vera Liang. May 21, 2018. Meet the farmworkers leading the \#MeToo fight for workers everywhere, Civil Eats, https://civileats.com/2018/05/21/meet-the-farmworkersleading-the-metoo-fight-for-workers-everywhere/

Cole, J. 2018. Service providers' perspectives on sex trafficking of male minors: comparing background and trafficking situations of male and female victims. Child and Adolescent Social Work Journal 35 (4): 423-433. 
Collins, Patricia Hill. 2005. Black Sexual Politics. New York: Routledge.

Collins, Patricia Hill. 2000. Black Feminist Thought: Knowledge, Consciousness, and the Politics of Empowerment. New York: Routledge.

Cottom, Tressie McMillan. 2013. When your brown body is a white wonderland, http://tressiemc.com/2013/08/27/when-your-brown-body-is-a-white-wonderland/

Crenshaw, Kimberlé Williams. 1994. The marginalization of sexual violence against Black women. NCASA Journal, a publication of the National Coalition Against Sexual Assault 2 (1): 1-15.

Davis, Angelique and Rose Ernst. 2019. Racial gaslighting. Politics, Groups, and Identities 7 (9): 761-74 https://doi.org/10.1080/21565503.2017.1403934 (published online 2017)

Davis, Angela. 1983. Women, race, and class. Random House: New York.

Davis, Emmalon. 2018. On epistemic appropriation. Ethics 128 (4): 702-27.

Dotson, Kristie. 2019. On the costs of socially relevant philosophy papers: a reflection. Journal of Social Philosophy. https://doi.org/10.1111/josp.12297

Dotson, Kristie. 2012. A cautionary tale: on limiting epistemic oppression. Frontiers 33 (1): 24-47.

Dotson, Kristie. 2011. Tracking epistemic violence, tracking practices of silencing. Hypatia 26 (2): 236-57.

Fair Food Program. 2017. Fair food annual report. https://www.fairfoodprogram.org

Fricker, Miranda. 2007. Epistemic injustice: power and the ethics of knowing. Oxford: Oxford University Press.

Fricker, Miranda. 2006. Powerlessness and social interpretation. Episteme 3 (1-2): 99108. 
Frye, Marilyn. 1983. The politics of reality: essays in feminist theory. Trumansburg, NY: The Crossing Press.

Greenhouse, Steven. Sept 1 2009. Low-wage workers are often cheated, study says. The New York Times. https://www.nytimes.com/2009/09/02/us/02wage.html

Gwaltney, John Langston. 1993. Drylongso: A self-portrait of Black America. New York: The New Press.

Human Rights Watch. 2012. Cultivating fear: the vulnerability of immigrant farmworkers in the US to sexual violence and sexual harassment. https://www.hrw.org/report/2012/05/15/cultivating-fear/vulnerability-immigrantfarmworkers-us-sexual-violence-and-sexual

King, Deborah. 1988. Multiple jeopardy, multiple consciousness: the context of a Black feminist ideology. Signs 14 (1): 42-72.

Lipsitz, Raina. October 2017. Sexual harassment law was shaped by the battles of Black women, The Nation.

Lockhart, P.R. Dec 2017. Women of color in low-wage jobs are being overlooked in the \#MeToo moment, Vox. https://www.vox.com/identities/2017/12/19/16620918/sexualharassment-low-wages-minority-women.

Mackinnon, Catherine. 1979. Sexual harassment of working women: a case of sex discrimination. New Haven: Yale University Press.

Mason, Rebecca. 2011. Two kinds of unknowing. Hypatia 26 (2): 294-307.

May, Vivian M. 2014. "Speaking into the void"? Intersectionality critiques and epistemic backlash. Hypatia 29 (1):94-112.

McKinnon, Rachel. 2017. Allies behaving badly: gaslighting as epistemic injustice. In Gaile Pohlhaus Jr., Ian James Kidd, and José Medina (Eds.), Routledge Handbook on Epistemic Injustice. New York: Routledge. 
Medina, José. 2013. Epistemologies of resistance: gender and racial oppression, epistemic injustice, and resistant imaginations. Oxford: Oxford University Press

Mills, Charles. 2007. White ignorance. In Shannon Sullivan and Nancy Tuana (Eds.). Race and epistemologies of ignorance (11-38). Albany: State University of New York Press.

Mohanty, Chandra. 1988. Under western eyes: feminist scholarship and colonial discourses. Feminist Review 30: 61-88.

Ortega, Mariana. 2006. On being lovingly, knowingly ignorant: white feminism and women of color. Hypatia 21 (3):56-74.

Pohlhaus, Gaile. 2012. Relational knowing and epistemic injustice: toward a theory of willful hermeneutical ignorance. Hypatia 27(4), 715-735.

Pohlhaus, Gaile. 2017. Gaslighting, echoing, and gathering; or why collective epistemic resistance is not a "witch hunt." Gaslighting and Epistemic Injustice Conference, Claremont McKenna College, September 23, 2017.

Roberts, Dorothy. 1997. Killing the Black body. New York: Random House.

Ruíz, Elena Flores. 2014. Musing: spectral phenomenologies: dwelling poetically in professional philosophy. Hypatia, 29(1), 196-204.

Ruíz, Elena Flores. 2012. Theorizing multiple oppressions through colonial history: cultural alterity and Latin American feminisms, APA Newsletter on Hispanic/Latino Issues in Philosophy 11(2): 5-9.

Ruíz, Elena Flores, 2019a. The secret life of violence. In Frantz Fanon and Emancipatory Social Theory, Dustin Byrd (ed). Boston: Brill Press.

Ruíz, Elena Flores. 2019b. Between hermeneutic violence and alphabets of survival. In Andrea Pitts, Mariana Ortega \& José Medina (eds.), Theories of the flesh: Latinx and Latin American feminisms, transformation, and resistance. Oxford University Press. 
Ruíz, Elena Flores. forthcoming. Cultural gaslighting. Hypatia.

Ruíz, Elena Flores. manuscript. Structural violence.

Silva, Noenoe. 2004. Aloha betrayed: Native Hawaiian resistance to American colonialism. Duke University Press.

Spillers, Hortense. 1984. Interstices: a small drama of words, in Carole S. Vance (ed). Pleasure and danger: exploring female sexuality. Boston: Routledge.

Tompkins, Kyla Wazana. Sep 13 2016. We aren’t here to learn what we already know. Avidly: A channel of the Los Angeles Review of Books. http://avidly.lareviewofbooks.org/2016/09/13/we-arent-here-to-learn-what-we-know-wealready-know/

Tremain, Shelley. 2016. Knowing disability, differently, in The Routledge Handbook on Epistemic Injustice, I.J. Kidd, J. Medina, and G. Pohlhaus, Jr. (eds). New York: Routledge.

Tremain, Shelley. 2017. Foucault and feminist philosophy of disability. Ann Arbor: University of Michigan Press.

Waugh, Irma Morales. January 2010. Examining the sexual harassment experiences of Mexican immigrant farmworking women. Violence Against Women 16 (3): 237-61.

Wells-Barnett, Ida B. 1900. Lynch Law in America, in Beverly Guy-Sheftall (ed). Words of fire: an anthology of African-American feminist thought. New York: The New Press.

Wohl, Jessica. Apr 1 2014. Survey: Almost 90\% of fast-food workers allege wage theft. The Chicago Tribune. https://www.chicagotribune.com/news/nationworld/chi-surveyalmost-90-of-fastfood-workers-allege-wage-theft-20140401-story.html

Young, Cate. Jan 10 2014. This is what I mean when I say 'white feminism.' https://www.cate-young.com/battymamzelle/2014/01/This-Is-What-I-Mean-When-I-SayWhite-Feminism.html 
Zimmerman, Jean. Apr 16 2016. The agonizing collision of love and slavery.

Npr.org http://www.npr.org/2016/04/06/471619275/the-agonizing-collision-of-love-andslavery-in-thomas-jefferson 